\title{
PENDEKATAN MITIGASI DAN ADAPTASI PERUBAHAN IKLIM MELALUI REKLAMASI LAHAN DAN KONSERVASI AIR
}

\author{
Rr Diah Nugraheni Setyowati ${ }^{1}$, Fajar Susilowati² \\ ${ }^{1}$ Fakultas Sains dan Teknologi, UIN Sunan Ampel, Jl Ahmad Yani 117 Surabaya \\ ${ }^{2}$ Jurusan Teknik Sipil, Universitas Tidar, Jl. Kapten Suparman 39 Magelang \\ Idiahnugraheni@uinsby.ac.id, fajar.susilowati@untidar.ac.id
}

\begin{abstract}
Climate change is a condition of temperature change and rainfall distribution. Extreme climate events or anomalies such as very high rainfall intensity in short time cause floods and landslides. There is no rain in a long time that will cause drought. Flood and landslide disasters are a form of hydrological disaster in this study. The approach to mitigation and adaptation to climate change focused on how to prevent the occurrence of hydrological disasters, namely land reclamation and water conservation. The method of this research was descriptive research. Descriptive research methods aimed at describing, explaining, and validating the phenomena which became the object of this research. From the recapitulation results of the Indonesian Central Statistics Agency, the temperature of the last 25 years has increased dramatically to reach around $7.5^{\circ} \mathrm{C}$. While rainfall figures have also experienced significant fluctuations. The ups and downs are not easily predicted, which will have an impact on human activities in daily life. To anticipate the climate change in Indonesia, two policy approaches are used to develop development patterns, namely mitigation and adaptation. In the concept of a mitigation approach based on research results, intermittent irrigation has proven to be effective. The concept of adaptation approach about the development of the database system expected that the primary foundation for the government and the community was the early warning system for disasters. Principally, the ways of handling climate change mitigation and adaptation through land reclamation and water conservation are quite extensive and varied. The latest in the implementation is the reclamation of ex-mining land, the development of agroforestry systems, and rainwater harvesting systems.
\end{abstract}

Keywords: Mitigation, Adaptation, Climate, Conservation, Water.

\begin{abstract}
ABSTRAK
Perubahan iklim adalah kondisi perubahan suhu dan distribusi curah hujan. Kejadian atau anomali iklim ekstrem seperti intensitas curah hujan yang sangat tinggi dalam waktu singkat menyebabkan banjir dan tanah longsor. Tidak ada hujan dalam waktu lama yang akan menyebabkan kekeringan. Bencana banjir dan tanah longsor adalah bentuk bencana hidrologi dalam penelitian ini. Pendekatan mitigasi dan adaptasi terhadap perubahan iklim berfokus pada bagaimana menangani terjadinya bencana hidrologi, yaitu reklamasi lahan dan konservasi air. Metode yang digunakan dalam penelitian ini adalah bentuk penelitian deskriptif. Metode penelitian deskriptif memiliki tujuan untuk mendeskripsikan, menjelaskan, dan memvalidasi fenomena yang menjadi objek penelitian. Dari hasil rekapitulasi Badan Pusat Statistik Indonesia, suhu 25 tahun terakhir telah meningkat secara dramatis hingga mencapai sekitar 7,5 ${ }^{\circ}$. Sementara angka curah hujan juga mengalami fluktuasi yang signifikan. Pasang surut tidak mudah diprediksi, yang akan berdampak pada aktivitas manusia dalam kehidupan sehari-hari. Untuk mengantisipasi perubahan iklim di Indonesia, dua pendekatan kebijakan digunakan untuk mengembangkan pola pembangunan, yaitu mitigasi dan adaptasi. Dalam konsep pendekatan mitigasi berdasarkan hasil penelitian, irigasi intermiten terbukti efektif. Konsep pendekatan adaptasi tentang pengembangan sistem basis data diharapkan menjadi fondasi utama bagi pemerintah dan masyarakat dalam sistem peringatan dini untuk bencana. Pada prinsipnya, cara penanganan mitigasi dan adaptasi perubahan iklim melalui reklamasi lahan dan konservasi air cukup luas dan beragam. Yang terbaru dalam implementasi adalah reklamasi lahan bekas penambangan, pengembangan sistem agroforestri, dan sistem pemanenan air hujan (rain water harvesting).
\end{abstract}

Kata kunci: Mitigasi, Adaptasi, Iklim, Konservasi, Air. 


\section{PENDAHULUAN}

\section{Latar Belakang}

Indonesia merupakan wilayah kepulauan yang terletak di antara pertemuan 3 (tiga) lempeng raksasa yaitu Eurasia, IndoAustralia dan Pasifik. Indonesia diketahui berada pada rangkaian wilayah cincin api (ring of fire), sehingga memiliki peluang yang cukup tinggi terhadap terjadinya bencana terutama yang berkaitan dengan hidrologi, geologi dan vulkanologi [1].

Sebagai negara yang merupakan wilayah kepulauan dan mempunyai iklim tropis, perubahan iklim akan mempengaruhi banyak bidang, antara lain pertanian, perikanan, infrastruktur, kelautan, kesehatan, pembangunan, sosial dan ekonomi [2].

Menurut Badan Nasional Penanggulangan Bencana (BNPB), kejadian bencana di Indonesia dalam periode tahun 1918 hingga tahun 2018 sebesar $88 \%$, terutama terkait dengan iklim [3]. Perubahan iklim dapat dilihat pada beberapa indikator berikut ini, yaitu: suhu udara, curah hujan, hari hujan, lamanya penyinaran dan kecepatan angin [4].

Berdasarkan data dari LAPAN dan BMG, indikator curah hujan merupakan faktor yang paling banyak mempengaruhi timbulnya bencana alam seperti banjir dan longsor. Berikut ini adalah gambar akumulasi curah hujan di Indonesia [5].

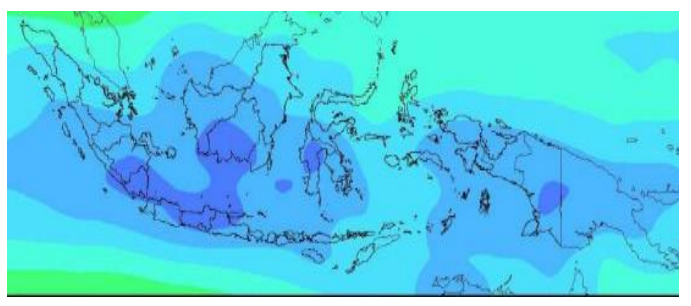

Gambar 1. Akumulasi Curah Hujan Indonesia [6]

Dampak perubahan iklim yang akan dan sudah terjadi antara lain berupa adanya peningkatan suhu udara, kenaikan permukaan air laut, adanya perubahan curah hujan, peningkatan frekuensi, dan ditemukan pula intensitas kejadian cuaca ekstrem. Kejadian iklim ekstrem atau anomali seperti intensitas curah hujan yang sangat tinggi pada waktu singkat menyebabkan banjir dan longsor atau sebaliknya tidak ada hujan dalam waktu lama akan menyebabkan kekeringan [7].

Bencana banjir dan longsor yang merupakan salah satu bentuk bencana hidrologis, sehingga pada penelitian ini pendekatan mitigasi dan adaptasi perubahan iklim difokuskan pada bagaimana cara penanganan adanya bencana hidrologis, yaitu dengan reklamasi lahan dan konservasi air [8].

\section{Permasalahan}

Permasalahan dalam penelitian ini fokus pada masalah perubahan iklim di Indonesia dan bagaimana cara penanganan bencana hidrologis akibat adanya perubahan iklim dengan pendekatan mitigasi dan adaptasi perubahan iklim, melalui reklamasi lahan dan konservasi air.

\section{Tujuan dan Manfaat}

Tujuan yang ingin dicapai dalam penelitian ini adalah mengkaji adanya perubahan iklim dan cara penanganan adanya bencana hidrologis akibat adanya perubahan iklim dengan pendekatan mitigasi dan adaptasi perubahan iklim, melalui reklamasi lahan dan konservasi air.

Manfaat penelitian ini adalah dapat menambah informasi kepada masyarakat Indonesia mengenai pendekatan mitigasi dan adaptasi perubahan iklim melalui reklamasi lahan dan konservasi air. 


\section{Landasan Teori}

Perubahan iklim merupakan kondisi berubahnya temperatur dan distribusi curah hujan. Perubahan iklim membawa dampak luas terhadap berbagai sektor kehidupan manusia. Pada skala global, perubahan iklim merupakan variasi ratarata kondisi iklim pada suatu tempat atau pada variabilitasnya yang nyata secara statistik dalam jangka waktu yang panjang [9].

Perubahan iklim juga dapat menyebabkan adanya peningkatan curah hujan di wilayah tropis sebesar 0,2$0,3 \%$. Namun sebaliknya, di beberapa wilayah Asia dan wilayah Afrika, frekuensi dan intensitas kekeringan justru mengalami peningkatan. Selanjutnya, episode hangat karena kejadian El Nino Southern Oscillation (ENSO) menjadi semakin meningkat sejak pertengahan 1970-an [10]. Berikut ini adalah gambar El Nino dan La Nina.

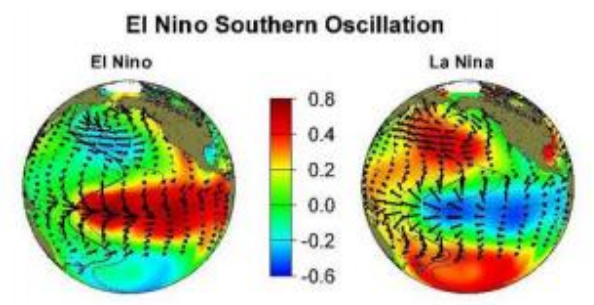

\section{Gambar 2. El Nino dan La Nina [11]}

Menurut Peraturan Menteri Pekerjaan Umum Nomor 11 Tahun 2011, Mitigasi Perubahan Iklim adalah suatu usaha pengendalian untuk mengurangi akibat adanya perubahan iklim melalui kegiatan yang dapat menurunkan emisi atau meningkatkan penyerapan GRK (gas rumah kaca) dari berbagai sumber emisi.

Sedangkan pengertian Adaptasi Perubahan Iklim berdasarkan Peraturan Menteri Pekerjaan Umum Nomor 11 Tahun 2011, adalah usaha yang dilakukan untuk meningkatkan kemampuan penyesuaian diri terhadap perubahan iklim, termasuk terhadap keragaman iklim dan kejadian iklim ekstrim, sehingga potensi kerusakan akibat perubahan iklim dapat berkurang, peluang yang ditimbulkan oleh perubahan iklim dapat dimanfaatkan dan konsekuensi yang ditimbulkan dapat diatasi.

Pendekatan mitigasi dan adaptasi perubahan iklim yang akan dilaksanakan meliputi pendekatan dalam bentuk reklamasi lahan dan konservasi sumber daya air. Reklamasi adalah kegiatan yang bertujuan untuk memperbaiki atau menata kegunaan lahan yang terganggu sebagai akibat adanya kegiatan usaha pertambangan, agar dapat berfungsi dan berdaya guna sesuai peruntukannya [12]

Umumnya istilah "reklamasi lahan" digunakan untuk menggambarkan dua kegiatan yang tidak sama. Reklamasi lahan dapat berupa kegiatan mengubah lahan basah/ jalur air menjadi lahan yang dapat digunakan dalam tujuan pengembangan.

Reklamasi lahan juga dapat berupa sebuah proses di mana lahan yang sudah rusak diupayakan untuk diperbaiki ke keadaan semula. Pada kedua kegiatan tersebut, istilah reklamasi lahan samasama digunakan membuat perubahan karakteristik lahan secara mendasar dalam rangka mencapai sebuah tujuan yang bermanfaat.

Reklamasi lahan dapat digunakan dalam upaya perbaikan kerusakan lingkungan hidup, reklamasi lahan juga dapat digunakan di wilayah tertentu dengan tujuan mengubah lahan kering menjadi tanah pertanian. Salah satu contoh lainnya adalah: sebuah pantai mengalami bencana abrasi yang cukup parah, maka perlu diambil tindakan beach nourishment, yaitu proses mengambil pasir dari tempat lain, kemudian diurukkan ke wilayah pantai yang sedang terkena bencana abrasi. Beach nourishment dapat digunakan 
untuk memperbaiki pantai yang rusak ke keadaan alaminya seperti semula.

Secara umum, reklamasi dapat dilakukan dengan 3 tahap, yaitu persiapan lahan, penanaman dan pemeliharaan. Persiapan lahan, meliputi: pengolahan tanah, pembuatan drainase, dan perbaikan tanah. Pelaksanaan penanaman pohon terbaik dilakukan di awal atau selama musim penghujan. Untuk mempermudah pelaksanaan pemeliharaan, pengawasan, dan evaluasi, pemasangan papan informasi di lokasi tanam harus dilakukan. Dengan demikian reklamasi terlaksana secara efektif [13].

Konservasi air pada prinsipnya merupakan aktivitas penggunaan air yang jatuh ke tanah untuk berbagai bidang secara efektif dan seefisien mungkin, dengan pengaturan waktu aliran air tertentu, dengan cara meresapkan air tersebut ke dalam tanah. Konservasi air mempunyai tujuan agar pada saat musim hujan datang tidak lagi terjadi banjir, dan sebaliknya pada saat musim kemarau datang, ketersediaan air untuk kebutuhan hidup manusia masih dapat terpenuhi [8].

Tujuan konservasi air antara lain sebagai berikut [14]:

- Menjamin ketersediaan air untuk generasi sekarang dan generasi yang akan datang,

- Penghematan energi yang cukup besar untuk aktivitas yang berkaitan dengan air

\section{METODE PENELITIAN}

Metode yang digunakan berupa penelitian deskriptif. Metode penelitian deskriptif mempunyai tujuan untuk mendeskripsikan, menjelaskan dan memvalidasi fenomena yang menjadi objek penelitian. Tahapan penelitian yang akan dilakukan antara lain sebagai berikut :
- Mempelajari isu perubahan iklim dan dampak perubahan iklim,

- Melakukan kajian pustaka yang terkait dengan perubahan iklim,

- Mempelajari kajian pustaka yang terkait dengan reklamasi lahan dan konservasi air,

- Melakukan kajian kebijakan yang terkait dengan perubahan iklim,

- Identifikasi potensi dan permasalahan terkait perubahan iklim,

- Identifikasi data statistik yang terkait dengan perubahan iklim,

- Pendekatan mitigasi dan adaptasi perubahan iklim melalui reklamasi lahan,

- Pendekatan mitigasi dan adaptasi perubahan iklim melalui konservasi air.

Berikut ini gambar diagram alir metode penelitian,

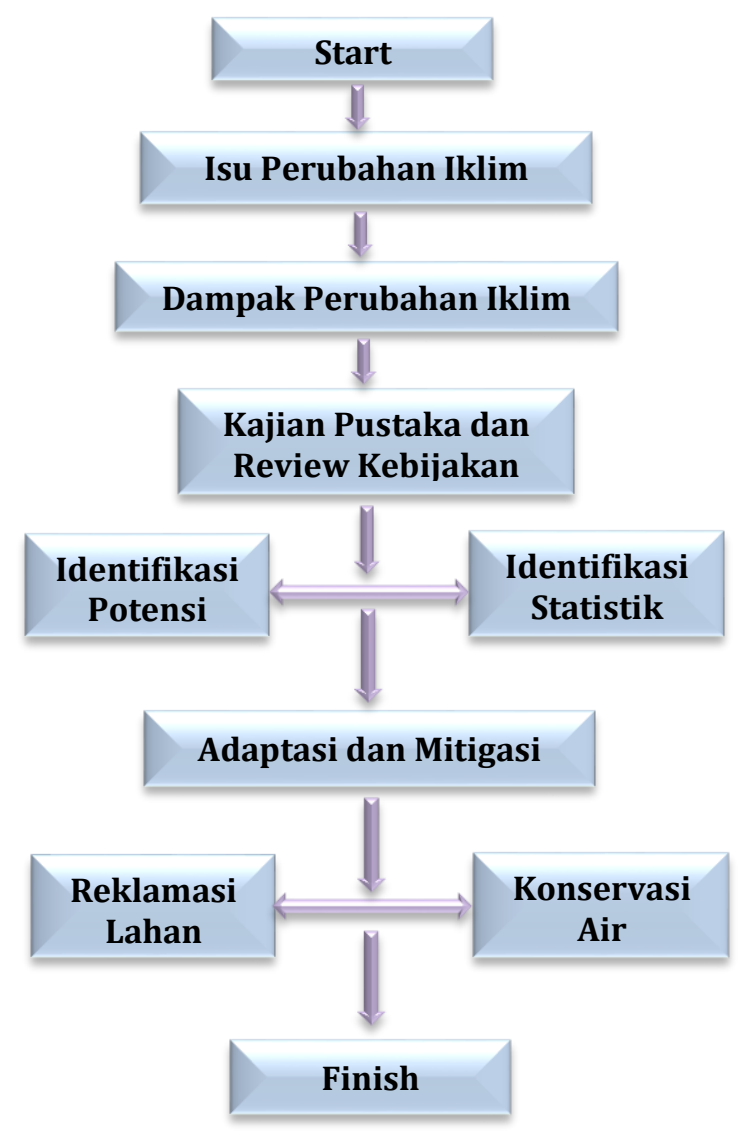

Gambar 3. Diagram Alir Metode Penelitian 


\section{HASIL dan PEMBAHASAN}

\section{Perubahan Iklim Mikro di Indonesia}

Dari hasil rekapitulasi Badan Pusat Statistik Indonesia, suhu udara 25 tahun terakhir mengalami peningkatan drastic hingga mencapai angka sekitar $7,5^{\circ} \mathrm{C}$. Sedangkan angka curah hujan juga mengalami fluktuasi yang signifikan, naik turunnya tidak mudah terpediksi, yang tentu saja hal ini akan berdampak pada aktivitas manusia dalam kehidupan sehari-hari [15].

\section{Konsep Pendekatan Mitigasi}

Langkah-langkah strategis yang diambil dalam pendekatan mitigasi perubahan iklim, antara lain:

- Pemantauan dan evaluasi daerah terjadinya bencana hidrologis

- Melakukan usaha hemat air, misal dengan mengurangi tinggi genangan pada lahan sawah, menghemat air untuk perkebunan, penggunaan aplikasi hidroponik, dll.

- Melakukan pengairan berselang (intermitten) sehingga dapat lebih mengefisienkan penggunaan air.

Pada konsep pendekatan mitigasi berdasar hasil penelitian, pengairan berselang atau intermitten terbukti efektif mengurangi emisi gas metan berkisar $17-66 \%$ daripada pengairan terus menerus, sehingga metoda ini juga dapat memutus daur hidup bakteri methanogen.

\section{Konsep Pendekatan Adaptasi}

Langkah-langkah strategis yang diambil dalam pendekatan adaptasi perubahan iklim, antara lain:

- Melakukan tindakan efektif dalam pemanfaatan informasi prakiraan iklim yang dapat digunakan sebagai bahan analisis terjadinya perubahan iklim.

- Optimalisasi pemanfaatan data dari stasiun pengamatan yang ada di Indonesia, untuk mempelajari fenomena iklim dan data sumberdaya air di Indonesia dengan akurat.

- Pemanfaatan peta wilayah rawan banjir dan kekeringan sbg informasi awal dalam memantau adanya banjir kekeringan dalam kondisi iklim normal.

- Mengembangkan sistem deteksi dini banjir dan kekeringan (early detection system for draught and flood) secara spasial dan temporal, dengan memanfaatkan penggunaan stasiun iklim dan penggunaan sarana telekomunikasi.

- Pengembangan sistem data base tanah, air dan iklim yang selalu up to date setiap saat, di setiap tingkat daerah otonomi, sebagai penstabilan mata rantai sistem database reklamasi lahan dan konservasi air.

Sistem data base ini diharapkan dapat menjadi pondasi utama bagi pemerintah dan masyarakat dalam sistem peringatan dini terhadap bencana banjir, bencana kekeringan dan anomali iklim di Indonesia.

\section{Reklamasi Lahan}

Langkah-langkah strategis yang diambil melalui proses reklamasi lahan, antara lain:

- Mekanisme Tanpa Olah Tanah (TOT). Mekanisme TOT dapat mengurangi $30 \%$ kondisi anaerob dalam tanah. Mekanisme ini efektif diterapkan di bidang pertanian dan perkebunan.

- Mencegah alih fungsi lahan pada beberapa lahan produktif sekaligus 
mengurangi aktifitas pembakaran hutan untuk pembukaan lahan pertanian baru.

- Perluasan areal diarahkan pada lahan lahan yang sudah dibuka tetapi sudah lama tidak produktif/ tidak dimanfaatkan.

- Mereklamasi lahan bekas pertambangan

- Mengembangkan sistem agroforestry untuk mereduksi konsentrasi $\mathrm{CO} 2$

\section{Konservasi Air}

Langkah-langkah strategis yang diambil melalui konservasi air antara lain:

- Meningkatkan daya dukung daerah aliran sungai dengan cara meminimalisir kerusakan dan memperbaiki catchment area sebagai daerah resapan air, baik dengan metode mekanik (pembuatan terasering, sumur resapan, biopori), maupun dengan metode vegetative (reboisasi daerah hulu dan hilir)

- Melakukan konservasi air dengan pemanenan air hujan (rain water harvesting) dan aliran permukaan (rainfall and runoff) pada musim hujan untuk dimanfaatkan pada saat terjadi krisis air. Cara pemanenan air hujan dilakukan dengan menampung air hujan melalui pembuatan embung, pemasangan tandon air dan bak penampungan air khusus.

- Mengembangkan adanya teknologi DAM parit yang dibangun pada beberapa alur sungai, teknologi ini bermanfaat untuk menambah kapasitas tampung sungai, dapat memperlambat laju aliran sungai dan dapat meresapkan air ke dalam tanah (recharging pattern). Teknologi ini dianggap efektif dalam menampung volume air yang ada dalam jumlah relatif besar dan dianggap efektif dalam mengairi areal yang relatif luas karena dapat dibangun secara berseri (cascade series).

- Memperbaiki saluran irigasi dan diharapkan dapat meningkatkan efisiensi pemanfaatan air irigasi atau dengan rehabilitasi/ perbaikan prasarana irigasi.

- Meningkatkan penggunaan potensi sumber daya air alternatif, baik potensi air permukaan maupun potensi air tanah dengan teknologi pompa air.

- Meningkatkan mobilisasi pompa air dengan gerakan society partisipatif bagi daerah yang masih tersedia sumber air.

- Mengoptimalkan adanya sistem gilirgiring pada sistem distribusi air irigasi (intermitten).

- Mengembangkan sistem irigasi berkelanjutan yang ramah lingkungan untuk menggurangi pemakaian bahan bakar seperti PATM (Pompa Air Tanpa Mesin), kincir air, dll

- Pengembangan bangunan konservasi air selain untuk mengatasi kelangkaan air, dapat meningkatkan produktivitas agroforestry. Untuk memanfaatkan air hasil konservasi air secara optimal, maka diperlukan teknologi irigasi yang memadai sesuai dengan kondisi spesifik lokasi.

Banjir dan kekeringan yang melanda lahan-lahan tidak sepenuhnya disebabkan dampak perubahan iklim. berdasarkan pemantauan di lapangan, banjir dapat pula disebabkan oleh kapasitas tampung daerah aliran sungai yang semakin berkurang, rusaknya jaringan drainase dan terjadinya alih fungsi lahan.

Sedangkan kekeringan dapat terjadi karena banyaknya pencurian air "illegal pumping" disepanjang jaringan, tidak ditaatinya kesepakatan golongan air, 
tidak adanya sumber air alternatif, infrastruktur irigasi rusak serta prioritas alokasi air antar sektor domestik dan non domestik.

\section{KESIMPULAN}

Dalam upaya untuk mengantisipasi perubahan iklim di Indonesia, dilakukan dengan dua pendekatan kebijakan yang merupakan pengembangan pola pembangunan yaitu mitigasi dan adaptasi. Pada konsep pendekatan mitigasi berdasar hasil penelitian, pengairan berselang atau intermitten terbukti efektif.

Pada konsep pendekatan adaptasi, pengembangan sistem data base tanah, air dan iklim yang selalu up to date setiap saat diharapkan dapat menjadi pondasi utama bagi pemerintah dan masyarakat dalam sistem peringatan dini terhadap bencana banjir, bencana kekeringan, dan anomali iklim di Indonesia.

Pada prinsipnya cara penanganan mitigasi dan adaptasi perubahan iklim melalui reklamasi lahan dan konservasi air cukup luas dan beragam, namun yang pelaksanaannya masih tergolong baru adalah reklamasi lahan bekas tambang dan pengembangan sistem agroforestry. Sedangkan untuk konservasi air pada dasarnya menekankan pada upaya memanen hujan "Rain Water Harvesting", yaitu dengan cara menampung air hujan dan air limpasan dalam suatu wadah sebagai cadangan air yang kelak dapat dimanfaatkan oleh masyarakat pada musim kemarau.

\section{UCAPAN TERIMAKASIH}

Terima kasih kepada LAPAN, BMG, BNPB, BPS dan semua pihak yang telah mendukung penelitian ini.

\section{DAFTAR PUSTAKA}

[1] N. A. Pambudi, "Geothermal power generation in Indonesia, a country within the ring of fire: Current status, future development and policy," Renewable and Sustainable Energy Reviews. 2018.

[2] A. Kadar, "Pengelolaan Kemaritiman Menuju Indonesia sebagai Poros Maritim Dunia," J. Keamanan Nas., 2015.

[3] BNPB, "Definisi dan Jenis Bencana," Psychological Bulletin. 2019.

[4] H. A. Rahman, "Global Climate Change and Its Effects on Human Habitat and Environment in Malaysia," Malaysian J. Environ. Manag., 2009.

[5] J. Sari, "Analisis Sebaran Curah Hujan Wilayah Menggunakan Metode Spi dan Hubungannya Dengan Indikator Iklim di Provinsi Sumatera Bara," Semin. Nas. Geomatika, 2018.

[6] Pusat Database BMKG, "DATA ONLINE - PUSAT DATABASE - BMKG," Pusat Database $B M K G, 2018$. .

[7] A. Susandi, I. Herlianti, M. Tamamadin, and I. Nurlela, "Dampak Perubahan Iklim Terhadap Ketinggian Muka Laut Di Wilayah Banjarmasin," $J$. Ekon. Lingkung., 2010.

[8] J. Linsley, Ray, K. \& Franzini, Teknik Sumber Daya Air. 2016.

[9] D. Hermon, "Mitigasi Perubahan Iklim," Rajawali Pers, 2018.

[10] C. Wang, C. Deser, J.-Y. Yu, P. DiNezio, and A. Clement, "El Niño and Southern Oscillation (ENSO): A Review," 2017.

[11] A. Timmermann et al., "El NiñoSouthern Oscillation complexity," Nature. 2018. 
[12] Arif I, "Perencanaan Tambang Total Sebagai Upaya

Penyelesaian Persoalan

Lingkungan Dunia

Pertambangan," 2007.

[13] R. D. N. S. Misbakhul Munir, "Kajian Reklamasi Lahan Pasca Tambang," KLOROFIL, vol. 1, no. 1, pp. 11-16, 2017.

[14] S. Arsyad, Konservasi Tanah. 2010.

[15] World Bank, "Adaptasi terhadap Perubahan Iklim," Policy Br., 2010. 